\title{
ANALISIS DAN EKSPERIMEN BLANK HOLDER GAP MINIMUM PADA PROSES RECTANGULAR CUP DEEP DRAWING
}

\author{
Susila Candra ${ }^{1}$, I Made Londen Batan ${ }^{2}$, Wajan Berata ${ }^{3}$, Agus Sigit Pramono ${ }^{4}$ \\ Teknik Manufaktur, Fakultas Teknik, Universitas Surabayal), Teknik Mesin, \\ Fakultas Teknologi Industri, Institut Teknologi Sepuluh Nopember (ITS) ${ }^{2,3,4)}$, \\ Sukolilo, Surabaya, 60111, Jawa Timur \\ E-mail : susila_c@staff.ubaya.ac.id-susilac@yahoo.com ${ }^{1}$,londbatan@me.its.ac.id ${ }^{2}$, \\ wayanb@me.its.ac.id ${ }^{3}$,pramono@me.its.ac.id
}

\begin{abstract}
This paper aims to investigate the magnitude of minimum blank holder gap to prevent wrinkles and cracks defects of the rectangular cup with T4 material Tin Plate CA. Punch-die domensions are determined based on the standard tool designed. The methods of this research are an analytic, finite element (FE), and experimental approach, respectively. Each method in this study had been mutually compared to other methods. According to the research, minimum blank holder gap is recommended by $120 \%$ to $130 \%$ of the thickness of the initial material (about $0.24 \div 0.26 \mathrm{~mm}$ ). By using the value of this gap, the height of wrinkles is very small, and the magnitude of the drawing force is still below the critical limit, so the product does not occur wrinkles and cracks.
\end{abstract}

Keywords : Blank Holder Gap, Rectangular Cup Product, Deep Drawing, Wrinkling, Cracking, Punch-Die Set, Drawing Force.

\section{PENDAhUluan}

Pengerutan (wrinkling) dan pecah (cracking) adalah dua jenis cacat produk yang sering terjadi pada proses deep drawing. Salah satu cara pencegahan cacat tersebut dapat dilakukan dengan penetapan gaya blank holder secara tepat dimana dapat tergambar dari ketinggian gap antara die dan blank holder.

Penetapan besarnya parameter tersebut dipengaruhi oleh beberapa faktor yaitu dimensi produk, jenis material dan tebal material. Pada pembentukan dimensi produk mangkuk (cup) yang relatif dangkal memang terkadang tidak diperlukan blank holder (Ali Hassan Saleh, Ammer Khalaf Ali, 2015). Akan tetapi untuk produk yang relatif dalam dengan perbandingan drawing ratio sekitar 1,7 2, blank holder menjadi bagian komponen perkakas yang diperlukan. Ketebalan blank sheet juga menjadi faktor penting yang menjadi pertimbangan dalam penetapan blank holder (Tahir Altinbalik, Aysun Tonka, 2012).

Peran blank holder dalam mengatasi masalah wrinkling dapat tergambar dari ketinggian gap, sehingga besarnya gap menjadi indikator penting untuk diperhatikan. Beberapa penelitian memberikan informasi bahwa gap optimal terjadi pada rentang harga yang sangat lebar. Penelitian yang dilakukan oleh Karem M, Younis et al menyaranlan gap berkisar $200 \%$ dari ketebalan awal material pada proses silindrical cup deep drawing. Penelitian yang dilakukan Gavas juga menetapkan gap pada rentang antara $150 \%$ s.d $200 \%$ dari ketebalan material pada proses square cup deep drawing (M. Gavas, M. Izciler dan M. Gavas, M. Izciler). Sedangkan untuk proses rectangular cup deep drawing dipastikan membutuhkan penetapan nilai gap yang tidak sama dibanding terhadap pembentukan cylindrical dan square cup.

Penelitian yang dilakukan oleh Jirasak Srirat et al menjaga gap secara konstan dan berbeda nilainya antara di awal dan akhir posisi punch stroke. Perbedaan nilai gap di awal dan diakhir punch stroke berkisaran rentang $150 \%$ s.d $180 \%$ dari ketebalan awal material (blank sheet). Di awal punch stoke, gap dijaga secara konstan sebesar $180 \%$ dari ketebalan blank sheet dan $160 \%$ di akhir punch stroke. Disamping itu blank holder 
force berubah secara fleksibel dengan menggunakan kontrol adaptive blank holder.

Simulasi variable blank holder force (VBHF) secara adaptive dilakukan juga oleh Z.Q.Sheng et al., dalam rangka menjaga gap agar lebih optimal. Nilai gap berkisar di dalam rentang angka 120\% sampai dengan $180 \%$ dari ketebalan material. Susila Candra et al juga membuat pemodelan matematis VBHF maksimal - minimal proses cylindrical cup deep drawing dengan acuan rentang gap minimal dan maksimal.

Berdasarkan beberapa informasi hasil penelitian sebelumnya, kemudian kajian pada paper ini akan diarahkan kepada pemodelan analitik sederhana, simulasi FE dan eksperimen tentang blank holder gap minimum pada proses rectangular cup deep drawing. Penelitian ini difokuskan pada proses pembentukan dengan bentuk rectangular cup dengan material kemasan Tin Plate T4 CA.

\section{KAJIAN PUSTAKA}

\subsection{Blank Holder Gap}

Wrinkling (pengerutan) disebut juga sebuah peristiwa buckling yang terjadi pada bagian flange produk, akibat dari tegangan tangensial yang terlalu besar jika dibanding dengan tegangan radialnya. Disamping itu peristiwa wrinkling dapat juga diindikasikan oleh terlalu besarnya perubahan bentuk material pada flange produk ke arah tangensial. Perubahan pembentukan di daerah flange dapat direpresentasikan oleh rasio perubahan bentuk atau rasio major strain (regangan radial - tarik) dan minor strain (regangan tangensial - tekan). Dari pendekatan tersebut kemudian kondisi aman pada proses pembentukan ini, mengikuti kaidah yang ada pada diagram forming limit diagram (FLD), seperti ditunjukkan pada gambar 1.

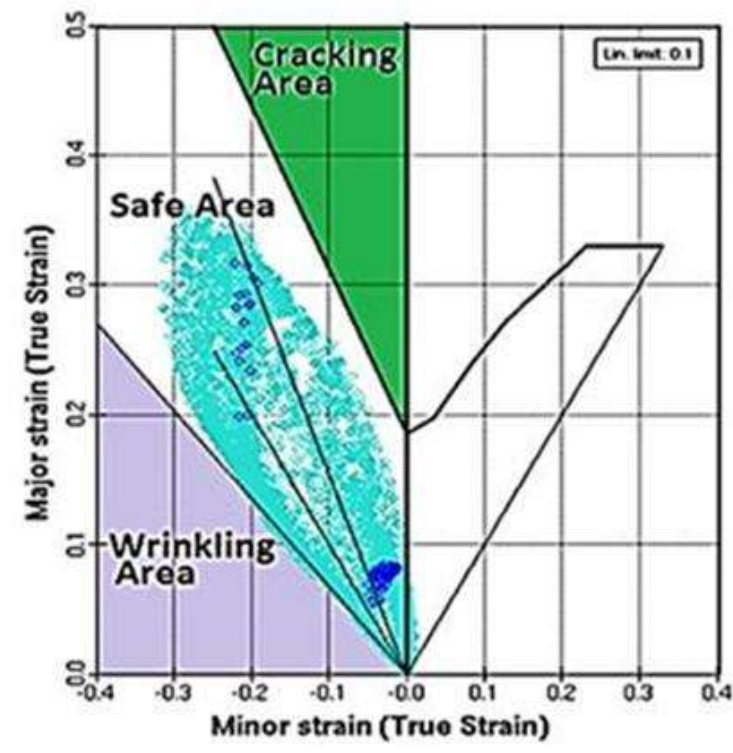

Gambar 1. Forming Limit Diagram.

(Schey, J.A, Lange, K)

Batasan regangan pembentukan (major and minor strain ratio) di daerah flange tersebut, selanjutnya digunakan sebagai syarat batas blank holder gap, tanpa wrinkling dan cracking. Regangan pembentukan mayor yang diyatakan sebagai regangan radial $\left(\mathrm{e}_{1}=\mathrm{e}_{\mathrm{r}}\right)$ di daerah flange produk dapat digunakan persamaan berikut :

$\varepsilon_{1}=\ln \left(\mathrm{d}_{0} / \mathrm{d}_{\mathrm{p}}\right)$

Dimana $\mathrm{d}_{0}$ adalah diamater awal blank sheet dan $d_{p}$ adalah diamater punch. Jika produk berbentuk rectangular cup, $\mathrm{d}_{0}$ dan $\mathrm{d}_{\mathrm{p}}$ masing-masing adalah sebagai diameter pojok dari blank sheet dan punch. Jika proses deep drawing diasumsikan kondisinya tidak ada perubahan kearah sumbu tegak (sumbu z) maka tegangan tangensial dapat dianggap sama dengan tegangan kearah ketebalan $\left(\varepsilon_{2}=\varepsilon_{3}\right)$. Tegangan kearah ketebalan dapat didekati dengan persamaan :

$$
\varepsilon_{2}=\ln \left(\mathrm{S}_{1} / \mathrm{S}_{0}\right)=\ln \left[\mathrm{Gap} / \mathrm{S}_{0}\right]
$$


Dengan mengacu pada diagram foming limit di atas dan diasumsi rasio regangan mayor dan minor maksimum yaitu sebanding dengan harga Limiting Drawing Ratio bahan (LDR $\mathrm{Lahan}_{\text {bak }}$, maka penggabungan persamaan (1) dan (2) menjadi.

$$
\text { Gap }=s_{1}=s_{0}\left(d_{0} / d_{p}\right)^{\mathrm{LDR}_{\text {behan }}}
$$

Pendekatan analitik lain dapat diuraikan berdasarkan teori dari Levy - Misses, dimana diperoleh persamaan diferensial pembentukan ke seluruh arah deformasi adalah sebagai berikut (Lange, $\mathrm{K}$ ) :

$\mathrm{d} \varepsilon_{1} / \sigma_{1}^{r}=\mathrm{d} \varepsilon_{2} / \sigma_{2}^{r}=\mathrm{d} \varepsilon_{3} / \sigma_{3}^{s}$

Dari dekomposisi tensor tegangan dan asumsi kondisi plane stress maka persamaan 4 menjadi :

$$
\sigma_{1}-\frac{\left(2 \sigma_{1}-\sigma_{3}\right)}{3} \sigma_{2}-\frac{\left(-\sigma_{1}-\sigma_{3}\right)}{3} \operatorname{dan} \sigma_{3}-\frac{\left(-\sigma_{1}-2 \sigma_{3}\right)}{3}
$$

Dengan menggabungkan persamaan (4) dan (5) selanjutnya persamaan menjadi :

$\mathrm{d} \varepsilon_{2}=\left(\sigma_{2}^{\prime} / \sigma_{3}^{\prime}\right) \mathrm{d} \varepsilon_{3}$

Kemudian setelah persamaan diintegrasikan akan menjadi :

$\varepsilon_{2}=\left(\left(-\sigma_{1}-\sigma_{3}\right) /\left(-\sigma_{1}+2 \sigma_{3}\right)\right) \varepsilon_{3}$

Jika $\varepsilon_{2}$ disebandingkan terhadap perubahan ketebalan atau gap, sehingga persamaan (7) akan menjadi :

$$
\begin{aligned}
& \varepsilon_{2}=\ln \left(s_{1} / s_{0}\right)= \\
& \left(\left(-\sigma_{p}-\sigma_{v}\right) /\left(-\sigma_{m}+2 \sigma_{v}\right)\right) \varepsilon_{z} .
\end{aligned}
$$

Persamaan (8) digunakan untuk memperkirakan ketebalan akhir sheet metal $\left(\mathrm{s}_{1}\right)$ sebagai representasi dari gap dengan persamaan sebagai berikut :

$G a p=S_{1}=S_{0} \operatorname{Exp}\left(\left(-\sigma_{r}-\sigma_{t}\right) /\left(-\sigma_{r}+2 \sigma_{t}\right)\right) \varepsilon_{t}$

Dengan mengacu pada diagram forming limit maka rasio regangan mayor dan minor diasumsikan sebesar 2, sehingga $=\mathrm{C} \varepsilon_{\mathrm{r}}=$

$\left(L D R_{\text {banan }}=1\right.$, dimana $\mathrm{LDR}_{\text {bahan }}$ digunakan nilai secara umum untuk baja yaitu 2 . Kemudian persamaan (9) dapat diubah menjadi :

$G a p=S_{0} \operatorname{Exp}\left(\frac{\left(-2 \sigma_{r}-1,15 \sigma_{\max , b_{a h a n}}\right)}{\left(-\sigma_{r}+2,3 \sigma_{\max , \text { bahan }}\right)}\right)$.

Dimana $\sigma_{\max \text { bahan }}$ adalah tegangan pembentukan maksimum yang disesuaikan dengan harga dari Ultimate Tensile Strenght Material (UTS) (Susila Candra). Sedangkan $\sigma_{\mathrm{r}}$ adalah tegangan radial yang dapat didekati dengan persamaan :

$\sigma_{\mathrm{r}}=\operatorname{UTS}\left(\left(\mathrm{d}_{0} / \mathrm{d}_{\mathrm{p}}\right)-0,7\right)$

Persamaan (3) dan (10) selanjutnya dipergunakan sebagai acuan pendekatan analitik, simulasi FE dan eksperiman dalam penetapan gap minimum pada proses deep drawing produk berbentuk cylindrical dan rectangular cup.

\section{METODE PENELITIAN}

3.1. Set up Percobaan dan Simulasi Finite Element

\subsubsection{Set $U p$ Percobaan}

Untuk menginvestigasi dan mengkonfirmasi blank holder gap minimum pembentukan produk rectangular cup deep drawing maka bentuk dan dimensi produk uji dapat ditetapkan seperti pada gambar 2 . Sedangkan bentuk punch-die dan sifat mekanik material yang digunakan dalam percobaan ini dapat dilihat pada tabel 1 dan tabel 2 . 

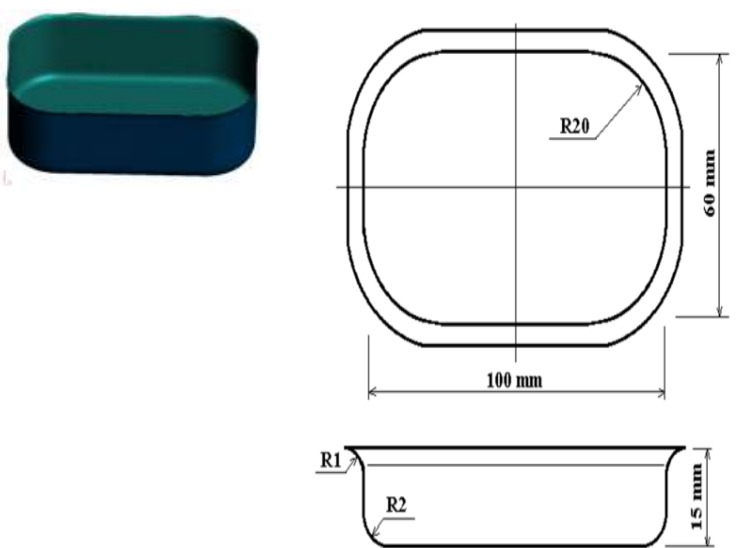

Gambar 2. Rectangular Cup Deep Drawing.

Tabel 1. Dimensi Punch Die Set dan Blank Sheet

\begin{tabular}{|c|c|c|}
\hline No & Dimensi & Nilai \\
\hline 1 & $\begin{array}{l}d_{0} \text { (diameter pojok dari } \\
\text { blank sheet) }\end{array}$ & $64 \mathrm{~mm}$ \\
\hline 2 & Lebar dan panjang die & $\begin{array}{c}60 \mathrm{~mm} \text { dan } \\
100 \mathrm{~mm}\end{array}$ \\
\hline 3 & $d_{z}($ dia. Die $) \rightarrow$ pojok die & $40 \mathrm{~mm}$ \\
\hline 4 & $d_{p}($ dia. Punch $)$ & $39,58 \mathrm{~mm}$ \\
\hline 5 & $2 x$ clearance & $0,58 \mathrm{~mm}$ \\
\hline 6 & $\begin{array}{l}s_{0}(\text { ketebalan awal blank } \\
\text { sheet) }\end{array}$ & $0,2 \mathrm{~mm}$ \\
\hline 7 & $r_{d}$ atmu $R_{1}$ (edge die radius) & $1 \mathrm{~mm}$ \\
\hline 8 & $\begin{array}{l}r_{p} \text { atau } R_{p}(\text { edge punch } \\
\text { radius) }\end{array}$ & $2 \mathrm{~mm}$ \\
\hline 9 & $\begin{array}{l}\mathrm{h} \text { (kedalaman rectangle } \\
\text { cup) }\end{array}$ & $16 \mathrm{~mm}$ \\
\hline
\end{tabular}

Tabel 2. Sifat Mekanik Material Tin Plate T4

\begin{tabular}{lll}
\multicolumn{3}{c}{ CA-B } \\
$\begin{array}{c}\text { Mech. Properties } \\
\text { Noterial Tin Plate T4 } \\
\text { CA-B }\end{array}$ & \multicolumn{1}{c}{ Nilai } \\
& \multicolumn{1}{c}{ Ka } & $559 \mathrm{~N} / \mathrm{mm}^{2}$ \\
1 & K & 0,176 \\
2 & Strain haedening (n) & $355 \mathrm{~N} / \mathrm{mm}^{2}$ \\
3 & UTS & $232 \mathrm{~N} / \mathrm{mm}^{2}$ \\
4 & Yield Stress & $1,78 \approx 1,8$ \\
5 & LDR $_{\text {bahan }}$ & \\
\hline
\end{tabular}

Skema punch-die set dan peletakan spacer ring sebagai ring pengatur jarak (gap) dapat diilustrasikan seperti gambar 3. Spacer ring dapat diganti sesuai keperluan gap yang akan diuji yaitu pada rentang $100 \%$ s.d 180
$\%$ dari ketebalan blank sheet. Sedangkan susunan lengkap punch-die set beserta spacer ring dan yang telah tersusun di atas mesin press ditunjukkan pada gambar 4 .

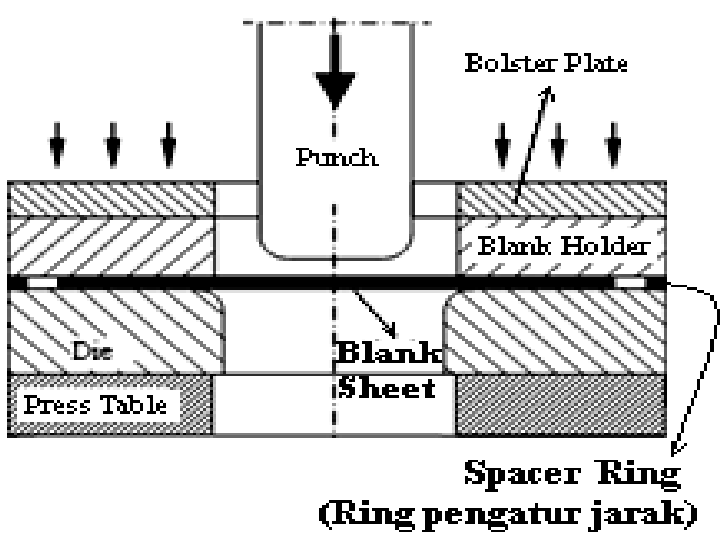

Gambar 3. Skema Punch-Die Set dan Posisi Spacer Ring.

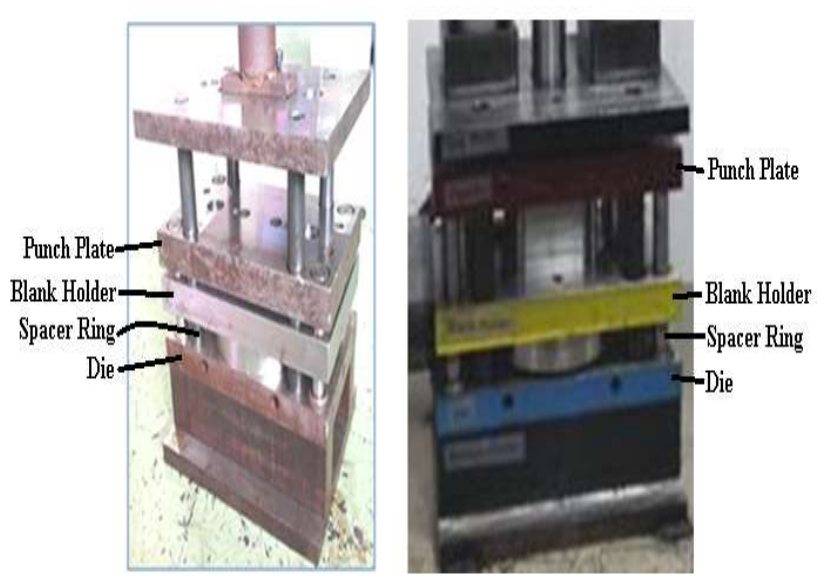

(a)

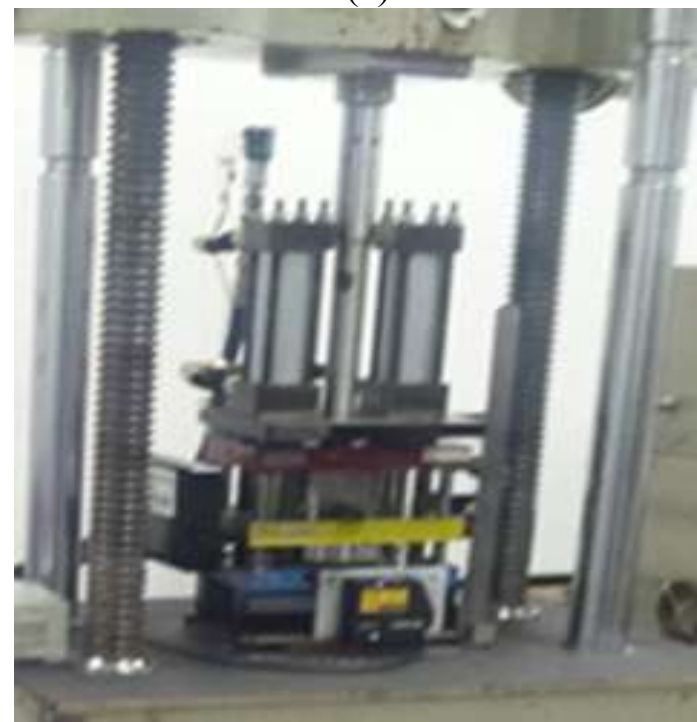

(b)

Gambar 4. a. Punch-Die Set. b. Punch-Die Set di Letakkan Pada Mesin Press. 


\subsection{Set Up Simulasi Finite Element (FE)}

Model FE pembentukan rectangular cup product yang akan disimulasikan dapat ditunjukkan pada gambar 5. Software simulasi FE menggunakan Autoform. Ver3.1 dengan prinsip deformasi pembentukan elastic - plastic dan mengabaikan faktor spring back. Kurva flow stress pada model $F E$ menggunakan formula Swift yang didalamnya mempertimbangankan flow yield stress dan plastic stress. Simulasi FE digunakan untuk prediksi kondisi deformasi produk dengan mengacu pada diagram forming limit curve (FLC) berdasarkan gap konstan pada rentang 100\%-180\% ketebalan blank sheet.

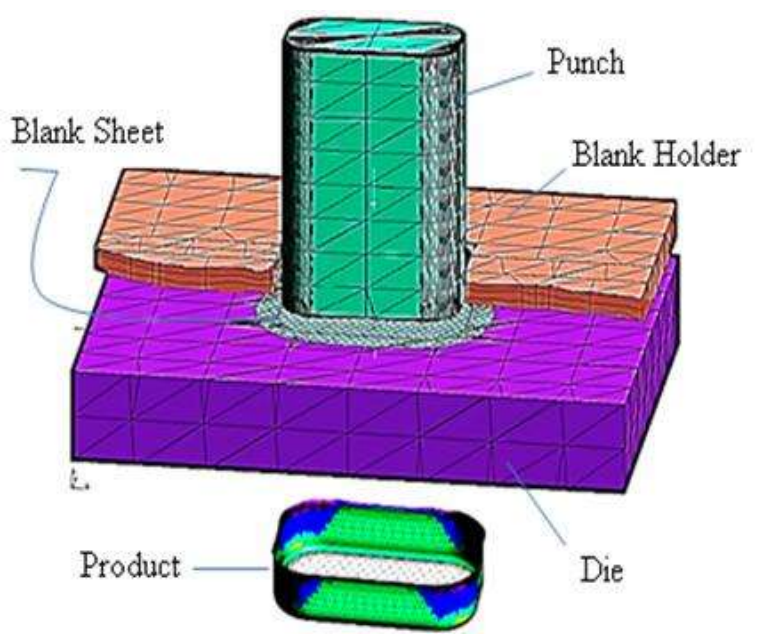

Gambar 5. Model FE.

4. HASIL DAN PEMBAHASAN

4.1. Hasil Analitik, Simulasi FE dan Eksperimen pembuatan Rectangular Cup Deep Drawing

\subsubsection{Pendekatan Analitik tentang Blank} Holder Gap - Rectangular Cup Deep Drawing

Dengan menggunakan persamaan (3) dan (10), nilai ketinggian blank holder gap minimum untuk proses rectangular deep drawing dengan material Tin Plate T4 CA-B diperoleh nilai masing-masing berkisar 0,24 $\mathrm{mm}$ dan $0,26 \mathrm{~mm}$. Nilai gap tersebut setara dengan angka ketinggian gap yang berkisar antara $120 \%$ dan $130 \%$ dari ketebalan blank sheet.
Ketinggian blank holder gap minumum tersebut diperkirakan dapat menghindarkan terjadinya wrinkling dan penipisan yang berlebih. Rentang harga blank holder gap tersebut diharapkan produk terhindar dari peristiwa wrinkling dan cracking. Nilai ketinggian gap tersebut selanjutnya akan diuji dan diverifikasi melalui simulasi FE dan eksperimen. Simulasi FE dan eksperiman dilakukan pada ketinggian gap $180 \%, 160 \%, 130 \%, 120 \%$ dan $100 \%$ dari ketebalan blank sheet $\left(s_{0}\right)$ atau setara masing-masing dengan $0,38 \mathrm{~mm}, 0,34 \mathrm{~mm}$, $0,26 \mathrm{~mm}, 0,24 \mathrm{~mm}$ dan $0,20 \mathrm{~mm}$.

\subsubsection{Simulasi FE - Rectangular Cup Deep Drawing}

Simulasi dimulai dengan menetapkan gap minimum sebesar $160 \%$ dari ketebalan blank sheet atau setara dengan $0.34 \mathrm{~mm}$. Hasil simulasi FE dapat ditunjukkan seperti gambar 6. Dengan penetapan gap tersebut akan dihasilkan ketingggian gelombang wrinkle sebesar $0,335 \mathrm{~mm}$. Dari gambar virtual tersebut menunjukkan ketinggian gelombang wrinkling sedikit muncul di setiap sisi pojok dari produk rectangular cup. Hal ini diperkirakan karena tegangan dan regangan tangensial masih sedikit mendominasi serta belum bisa dieliminasi dengan ketingguan gap tersebut. Meskipun demikian ketinggian gelombang wrinkling yang dihasilkan tidak menganggu pergerakan aliran material untuk masuk ke dalam die dan tidak berdampak terhadap terjadinya cracking.

Pada gambar 7, simulasi FE dilanjutkan dengan menetapkan gap konstan sebesar 130 $\%$ dari ketebalan blank sheet atau sekitar 0,264 mm. Hasil gambar virtual pada cross section di sisi pojok dari rectangular cup menunjukan ketinggian gelombang wrinkle sekitar 0,259 mm. Dari simulasi FE tersebut terlihat wrinkling dapat dihindari demikian juga dengan cracking. 


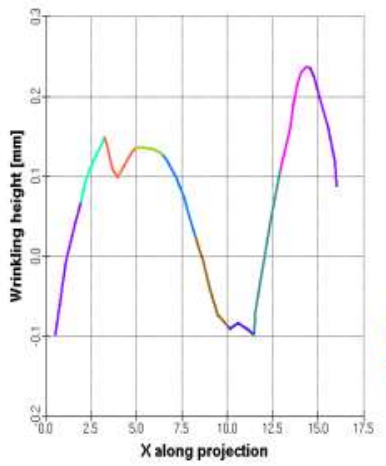

(a)

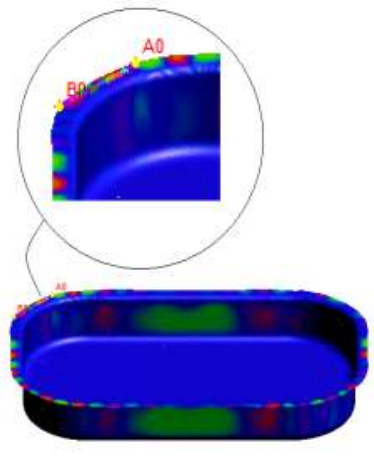

(b)
Gambar 6.a. Ketinggian Gelombang Wrinkle

Pada Penampang Cross Section Dengan Aplikasi Gap Sekitar 140 \% s.d 180 \% (ratarata $160 \%$ ) Ketebalan Blank Sheet.

Gambar 6.b. Posisi Cross Section Di Bagian Pojok Produk.

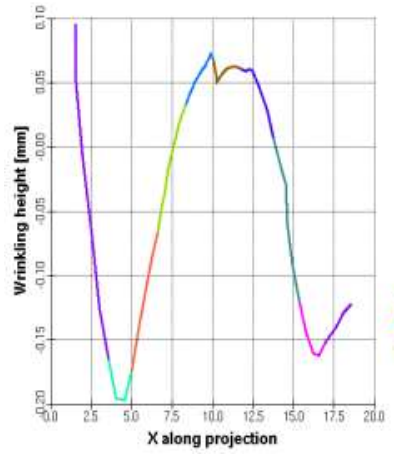

(a)

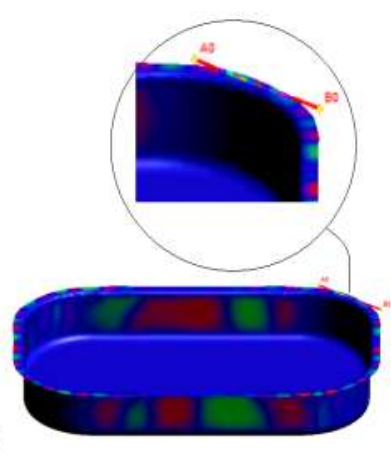

(b)
Gambar 7.a. Ketinggian Gelombang Wrinkle Pada Penampang Cross Section Dengan

Aplikasi Gap Sekitar 130\% Ketebalan Blank Sheet $(0.264 \mathrm{~mm})$. Gambar 7.b. Posisi Cross Section Di Bagian Pojok Produk.

Sedangkan gambar 8 merupakan hasil simulasi FE dengan penetapan gap sebesar $120 \%$ dari ketebalan blank sheet atau sekitar 0,24 mm. Dengan pengaturan gap secara konstan dengan nilai tersebut akan dihasilkan gelombang wrinkle sebesar 0,252 $\mathrm{mm}$ dimana wrinkling cenderung tidak tampak dan cracking tidak terjadi.

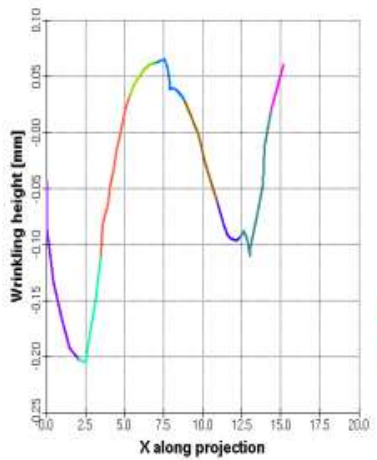

(a)

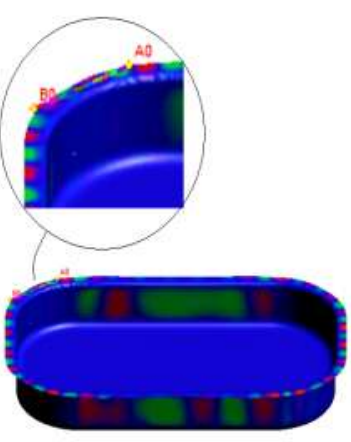

(b)
Gambar 8.a. Ketinggian Gelombang Wrinkle Pada Penampang Cross Section Dengan Aplikasi Gap Sekitar 120\% Dari Ketebalan Blank Sheet $(0.24 \mathrm{~mm})$.

Gambar 8.b. Posisi cross section dibagian pojok produk.

Jika gap ditetapkan lebih kecil dari 120 $\%$ dihasilkan produk cracking. Hal ini diperkirakan karena tegangan dan regangan radial telah mencapai harga kritisnya. Kondisi mulainya terjadi cracking dengan menggunakan gap $100 \%$ dapat ditunjukkan pada gamar 9.b.

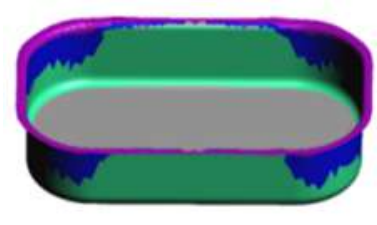

(a)

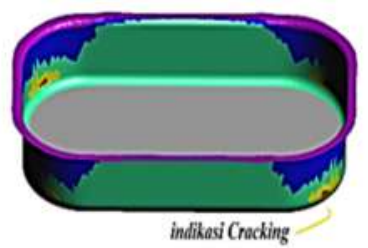

(b)

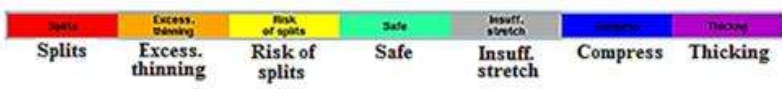

Gambar 9.a. Gambar Virtual dengan gap $120 \%$ dari ketebalan blank sheet belum cracking.

Gembar 9.b. Gambar Virtual dengan gap 100\% dari ketebalan blank sheet mulai cracking. 
Dari simulasi di atas memberikan informasi bahwa kondisi ideal dalam penetapan gap adalah pada rentang 120\% sampai dengan $130 \%$ dari ketebalan blank sheet. Pada rentang gap ini diperkirakan akan menahan peningkatan harga tegangan dan regangan tangensial. Demikian juga karena masih ada celah gap yang cukup sehingga aliran material ke arah radial masih dapat berlangsung dengan normal dan tegangan radial masih di bawah tegangan maksimal bahan yang diijinkan. Oleh karenanya secara fisik terjadi kondisi kesetimbangan nilai regangan radial (regangan mayor) dan regangan tangensial (regangan minor).

\subsection{Hasil Eksperimen dan Diskusi}

Hasil perhitungan analitis dan simulasi FE selanjutnya seluruh penetapan gap tersebut diverifikasi melalui percobaan dengan peralatan yang telah disetting seperti uraian di sub bab set up peralatan uji. Dari hasil percobaan menunjukkan bahwa peran penetapan blank holder gap memiliki peran yang sangat penting.

Gambar 10 menunjukkan hasil percobaan dengan penetapan blank holder gap sebesar $180 \%$ dan $160 \%$ dari ketebalan blank sheet atau masing-masing setara dengan $0.38 \mathrm{~mm}$ dan $0,34 \mathrm{~mm}$. Hasil percobaan pada penetapan gap tersebut menghasilkan produk dengan sedikit wrinkling ditunjukkan ketinggian gelombang wrinkle pada flange masing - masing sekitar $0,383 \mathrm{~mm}$ dan $0,345 \mathrm{~mm}$. Kondisi gelombang wrinkle pada rentang penetapan gap ini tidak mengakibatkan produk cracking.
Jika proses diteruskan dan diselesaikan sampai akhir punch stroke kondisi yang terjadi aliran material masuk ke dalam die tidak terhambat. Kondisi wrinkle ini tidak menggangu pergerakan aliran material ke dalam die dan produk tidak mengalami cracking, meskipun badan cup product terlihat ada sedikit bekas wrinkle berupa goresan sedikit di badan cup. Secara kualitas memang hal ini tidak membuat cacat wrinkling atau cracking tetapi kondisi proses khususnya dalam penetapan gap masih dapat dioptimalkan kembali. Hasil percobaan ini sesuai dengan hasil analitik dan simulasi FE yang telah diuraikan di sub bab sebelumnya.

Aplikasi gap sebesar 0,38 $\mathrm{mm}$ akan menghasilkan drawing force (gaya deep drawing) cenderung meningkat jika gap dikecilkan menjadi dan 0,34 mm. Gambar 11 menunjukkan bahwa dengan hasil drawing force tersebut masih dibawah drawing force kritisnya yaitu sekitar $17000 \mathrm{~N}$. Hal inilah yang dapat membuktikan secara kuantitatif bahwa produk tidak mengalami cracking atau aman dari terjadinya cacat cracking.

Dengan terdapatnya bekas goresan wrinkling di badan rectangular cup, maka penetapan gap pada rentang $140 \%$ sampai dengan $180 \%$ dari ketebalan blank sheet ini tidak disarankan menjadi referensi proses pembentukan deep drawing.

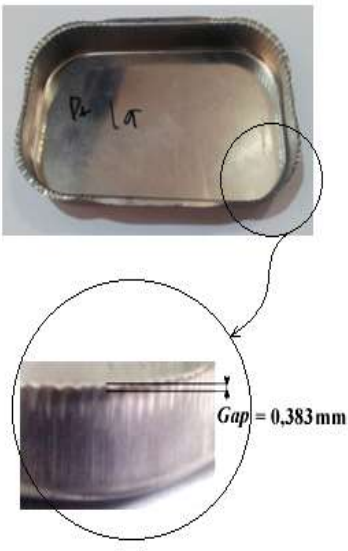

(a)

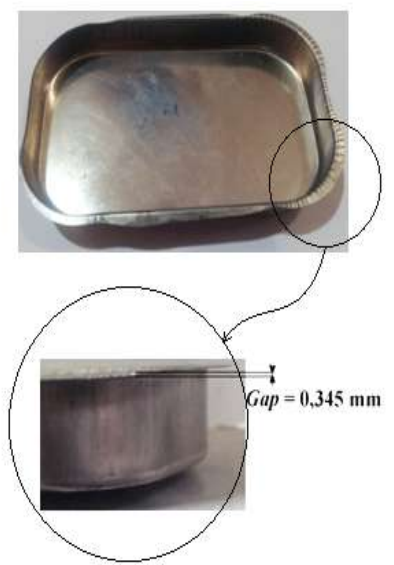

(b)
Gambar 10.a. Hasil Penetapan Gap 180\% dari Ketebalan Blank Sheet 0,38 mm.

Gambar 8.b. Hasil penetapan gap 160\% dari ketebalan blank sheet $0,34 \mathrm{~mm}$. 


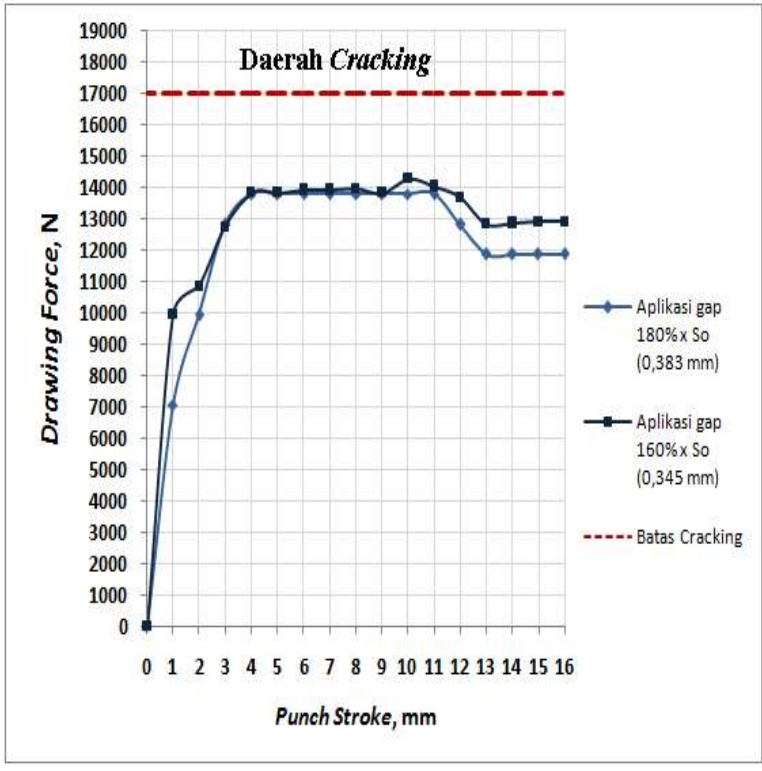

Gambar 11. Drawing Force Tiap Posisi

Punch Stroke Pada Penetapan Gap 180\% dan $160 \%$ dari Ketebalan Blank Sheet $(0,383$ dan 0,345 Mm), Produk Sedikit atau Cendenrung Wrinkle.

Percobaan berikutnya adalah mengurangi ketinggian blank holder gap dan ditetapkan sebesar $130 \%$ dan $120 \%$ dari ketebalan blank sheet atau setara dengan masing-masing sebesar $0,26 \mathrm{~mm}$ dan 0,24 $\mathrm{mm}$. Hasil percobaan seperti ditunjukan pada gambar 12 .

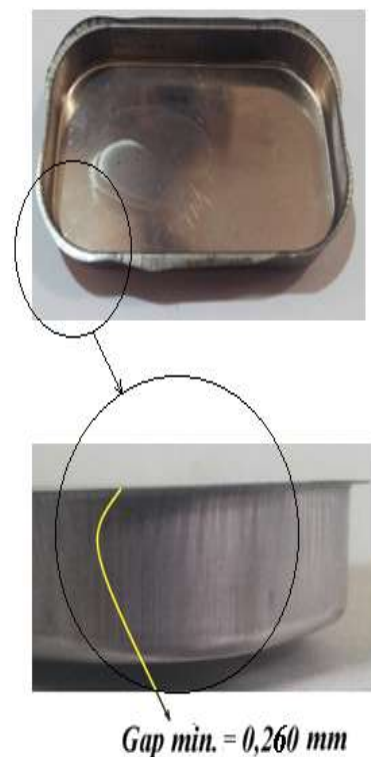

(a)

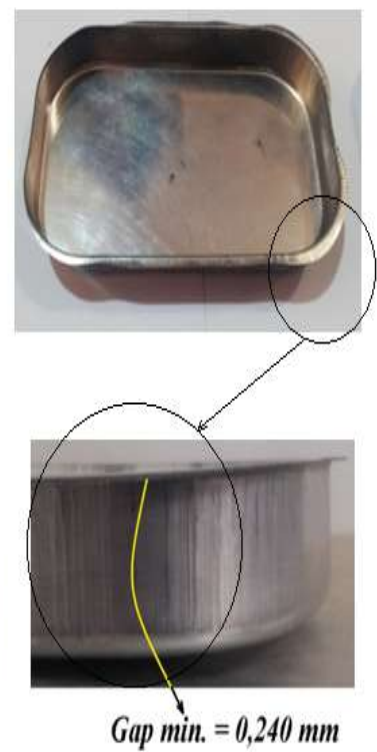

(b)
Gambar 12.a. Hasil Penetapan Gap 130\% dari Ketebalan Blank Sheet 0,26 mm.

Gambar 12.b. Hasil Penetapan Gap 120\% dari Ketebalan Blank Sheet 0,24 mm.
Hasil produk yang diperoleh dengan penetapan blank holder gap tersebut sesuai gambar 12 dipastikan tidak mengalami wrinkling dan cracking. Hasil percobaan lainnya seperti ditunjukkan gambar 13, dimana di setiap posisi punch stroke produk tidak mengalami cracking. Hal ini karena drawing force di setiap posisi punch stroke tidak melebihi harga kritisnya yaitu tidak melebihi 17000 N. Terjaganya drawing force ini menunjukkan dominasi tegangan radial atau tegangan tangensial dapat dihindari, dan secara fisik deformasi keseluruh arah mengalami kesetimbangan atau rasio major strain dan minor strain tidak terlalu besar yaitu berkisar di harga 1 .

Hasil penetapan gap ini membuktikan kesesuaiannya dengan hasil analitik dan simulasi FE serta dapat dipergunakan sebagai referensi proses untuk rectangular cup deep drawing.

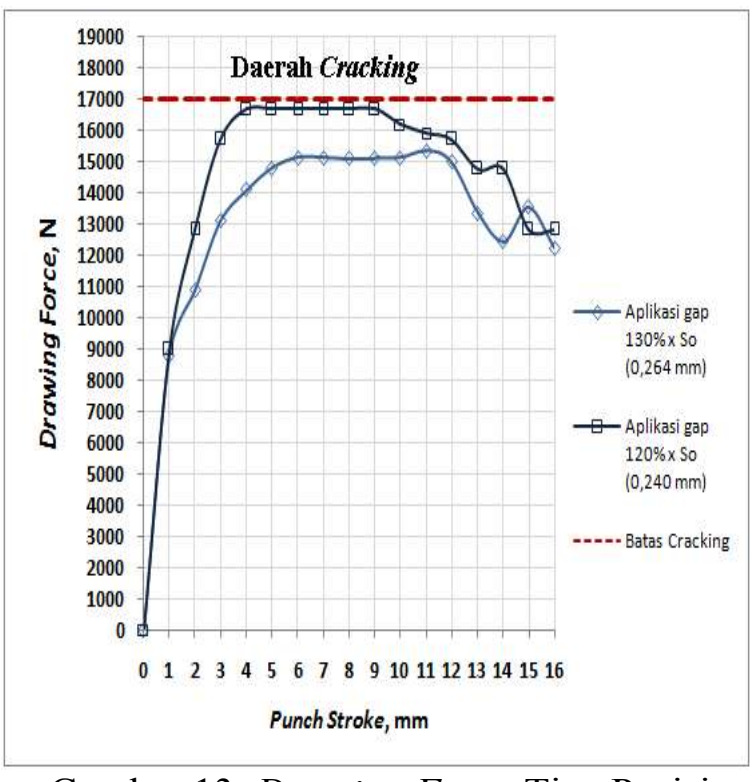

Gambar 13. Drawing Force Tiap Posisi Punch Stroke Pada Penetapan Gap 130\% dan $120 \%$ dari Ketebalan Blank Sheet (0,26 $\mathrm{mm}$ dan 0,24 mm), Produk Tidak Wrinkle dan Tidak Cracking.

Percobaan dilanjutkan dengan penggunaan ketinggian blank holder gap sebesar 100\% dari ketebalan blank sheet atau setara dengan $0,2 \mathrm{~mm}$ (sama dengan ketebalan blank sheet). Hasil percobaan dengan gap sebesar $0,2 \mathrm{~mm}$ dapat 
ditunjukkan gambar 14, dimana produk mengalami cracking seperti ditunjukkan pada gambar 14. Pada gambar 15 memberikan informasi besarnya drawing force di atas nilai kritisnya bahan yaitu 17.000 N. Dari percobaan ini dipastikan bahwa produk mengalami cracking dengan penggunaan gap sebesar 0,2 mm. Hasil ini sejalan dan sesuai dengan hasil analitik dan simulasi FE.

Dengan penetapan blank holder gap yang sangat sempit membuat tegangan radial dan rasio regangan mayor - minor akan sangat besar. Hal ini material di daerah flange mengalami regangan radial atau mayor lebih dominan di banding regangan minor yang akhirnya membuat penipisan berlebihan dan cracking tidak bisa dihindari.

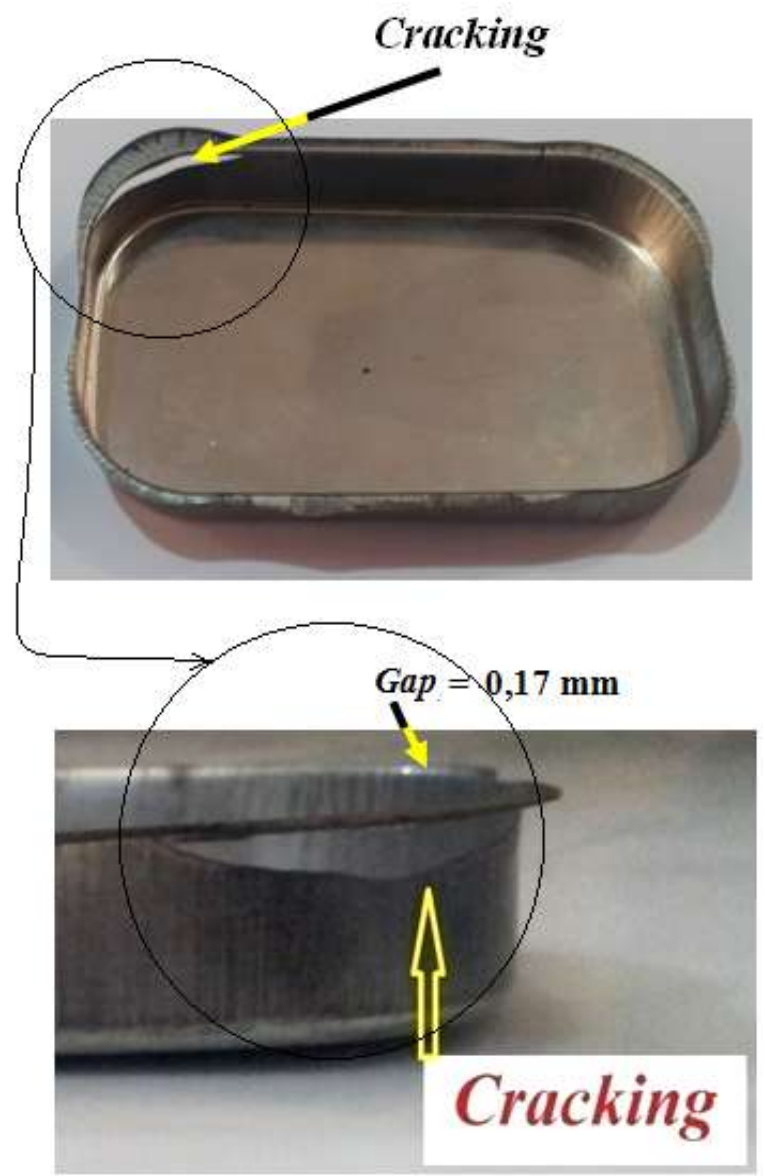

Gambar 14. Hasil Penetapan Gap 100\% dari Ketebalan Blank Sheet 0,2 mm.

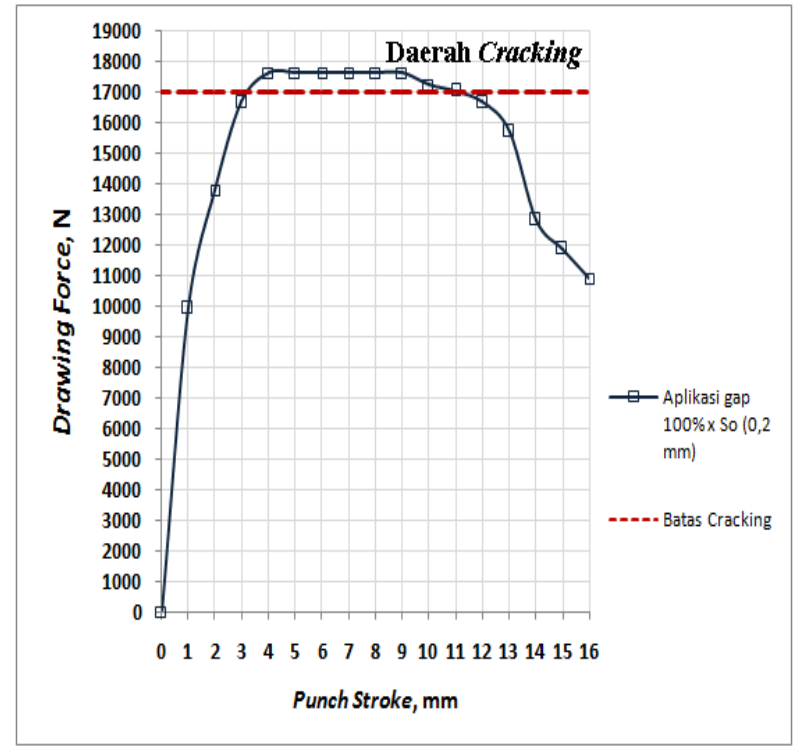

Gambar 15. Drawing Force Tiap Posisi

Punch Stroke Pada Penetapan Gap 100\% dari Ketebalan Blank Sheet 0,2 mm, Produk Cracking.

\section{KESIMPULAN}

Di dalam paper ini telah dihasilkan sebuah kajian analitik dan eksperimen terkait penetapan ketinggian blank holder gap minimum dengan tanpa cacat pruduk wrinkling dan cracking. Kesimpulan dari kajian ini adalah :

1. Kondisi paling kritis terjadi pada daerah pojok dari produk rectangular cup, karena di daerah tersebut terdapat dua kombinasi tegangan radial dan tegangan tangensial yang harus dijaga secara seimbang.

2. Penetapan blank holder gap akan mempengaruhi kondisi pembentukan, khususnya harga tegangan dan regangan pembentukan pada seluruh permukaan rectangular cup.

3. Kondisi mulai terjadinya gejala cracking dan wrinkling, secara fisik dapat dilihat dari perubahan gap sebagai indikasi dari perubahan tinggi gelombang wrinkling, dan harga drawing force sebagai indikasi dari besarnya penarikan material. Demikian juga, perubahan gap dapat dipergunakan untuk memastikan terjadinya tegangan tangensial yang berlebihan dan aliran material yang terlalu cepat pada arah alir tertentu. 
4. Ketinggian blank holder gap antara 140 $\%$ sampai dengan $180 \%$ akan menghasilkan produk sedikit wrinkle. Tetapi jika blank holder terlalu sempit yaitu sama dengan ketebalan blank sheet (100\% dari ketebalan blank sheet), kecenderungan produk rectangular cup mengalami cracking.

5. Ketinggian blank holder gap yang disarankan untuk kondisi proses ini adalah berkisar antara $120 \%$ sampai dengan $130 \%$ dari ketebalan blank sheet (sekitar 0,24 $\mathrm{mm}$ sampai dengan 0,26 $\mathrm{mm})$.

6. Jika ketinggian blank holder gap konstan menjadi pilihan maka perlu kajian lanjutan dalam perancangan punch die set agar penggunaannya lebih efektif dan efisien.

\section{Ucapan Terima Kasih}

Penulis ingin mengucapkan terima kasih kepada Fakultas Teknik Universitas Indonesia, khususnya kepada Prof Dr. Ir. Dedi Priadi, DEA., atas di perkenankannya menggunakan software AUTOFORM V1.3 untuk keperluan penelitian ini.

\section{DAFTAR PUSTAKA}

Ali Hassan Saleh, Ammer Khalaf Ali, "Development technique for deep drawing without blank holder to produce circular cup of brass alloy", International Journal of Engineering \& Technology, vol. 4 (1) pp.187-195, 2015.

Jirasak Srirat, Koetsu Yamazaki and Satoshi Kitayama," Optimization of Segmented Blank Holder Shape and Its Variable Blank Holder Gap in Deep-Drawing Process", Journal of Advanced Mechanical Design, Systems, and Manufacturing, Vol. 6, No. 4, pp. 420431, 2012.
Karem M, Younis,'Effect of Blank Holder Type on Deep Drawing Cups", The Iraqi Journal For Mechanical And Material Engineering, Vol.13, No.1, pp. 106-119, 2013.

Lange, K. Handbook of Metal Forming. USA: Mc-Graw Hill, USA. p. 20.120.66, 1985.

M. Gavas, M. Izciler, "Effect of blank holder gap on deep drawing of square cups", Materials and Design Vol. 28 pp. 1641-1646, 2007.

M. Gavas, M. Izciler, " Design and application of blank holder system with spiral spring in deep drawing of square cups", Journal of Materials Processing Technology, Vol. 171, pp. 274-282, 2006.

Schey, J.A. Introduction to manufacturing processes. Third Ed. Singapore: McGraw Hill; 2000. p. 408-419.

Susila Candra, I Made Londen Batan, Wajan Berata, Agus Sigit Pramono, "Modeling of Critical Blank Holder Force Based on a Gap Limit and Unbending Strain Energy in Deep Drawing Process", International Journal of Engineering and Technology, Vol 7 No 2 Apr-May, pp. 461-474, 2015.

Susila Candra, I Made Londen Batan, Wajan Berata, Agus Sigit Pramono, "Analytical study and FEM simulation of the maximum varying blank holder force to prevent cracking on cylindrical cup deep drawing", Procedia CIRP Vol. 26, pp. 548 - 553, 2015.

Tahir Altinbalik, Aysun Tonka, "Numerical and Experimental Study of Sheet Thickness Variation in Deep Drawing Processes", International Journal of Modern Manufacturing Technologies, ISSN 2067-3604, Vol. IV, No. 2 / 2012, pp. 9-10. 
Tommerup, S., Endelt, B., "Experimental Verification of a Deep Drawing Tool System for Adaptive Blank Holder Pressure Distribution", Journal of Materials Processing Technology, Vol. 212 pp. 2529-2540, 2012.

Z.Q Seng, S. Jirathearanat, T. Altan, (2004), "Adaptive FEM simulation for prediction of variable blank holder force in conical cup drawing", International Journal of Machine Tools \& Manufacture, Vol. 44, pp. 487-494, 2004.

Z.Q.Sheng, S.Jirathearanat,T. Altan, Adaptive FEM simulation for prediction of variable blank holder force in conical cup drawing, International Journal of Machine Tools and Manufacturing, Elsevier Ltd; 44: 487-494, 2004. 